\title{
Towards Reliable and Responsible Atrocities-Policing
}

\author{
Peter Penz
}

\begin{abstract}
As Rwanda and Yugoslavia indicate, atrocities policing ("humanitarian intervention") is, in our current global polity, unreliable and carried out crudely. This becomes apparent when it is compared with domestic policing. It is the result of the system of sovereign states, into which atrocities policing does not readily fit. Even innovation to accommodate it leads to the haphazard interventions we have seen in this decade. But the sovereignstate system, which developed in Europe in the context of a particular historical contingency and was then endowed to the rest of the world through decolonization, is not the only possible way of organizing the global polity. Thus, the author offers as an alternative the concept of a democratic global federation in which atrocities policing-including preventative policing - can be conducted in a much more reliable and responsible manner. While such a global political organization may seem utopian, in the long term it is not, given how radical change has been in the past century and can be expected to be in the next one. Moreover, it provides direction to current institutional reform and adds to current decisions about atrocities policing the issue of the longer-term consequences for global practices and institutions.
\end{abstract}

\section{Résumé}

Commelemontrent le Rwanda et la Yougoslavie, la gestion des atrocités (les «interoentions humanitaires») est, dans

Peter Penz has recently been appointed Director of the Centre for Refugee Studies, York University, Toronto. He is Associate Professor of Environmental Studies. His recent research has focused on the ethics of development-induced population displacement and on the tension between global justice and state sovereignty. The views expressed in the article are not the personal views of the author and not the collective position of the Centre. le dispositif de nos affaires publiques globales, menée cavalièrement, et de façon totalement non fiable. Cefait devient patent quand on établit la comparaison avec la gestion et au maintient del'ordre domestiques. Cette situation résulte du système de l'état souverain, au sein duquel la gestion des atrocités n'a pas vraiment sa place. Même les innooations visant a accommoder les choses n'ont $p u$ mener qu'd la série d'interventions improvisées de la dernière décennie. Or le système de l'état souverain, qui s'est développéen Europedans le contexted'une contingence historique particulière et fut ensuitedisséminé sur le restedu mode via la décolonisation, n'est pas l'unique façond'organiser la gestion globale. Ainsi l'auteur suggère, comme alternative, l'idée d'une fédération globale démocratique au sein de laquelle la gestion des atrocités-y compris leur gestion préventive-pourrait être menée d'une façon beaucoup plus fiable et responsable. Si une telle organisation politique semble a priori utopique, elle ne l'est pas à long terme, quand on considère les changements radicaux qui furent ceux du dernier siècle, et ceux quel'on peut envisager encore dans un proche avenir. Defait, ce programme suggère des directions aux réformes institutionnelles en cours, et ajouteaux décisions présentes en matière degestion des atrocités la prise en compte de la question des conséquences à long terme de ce type de situation sur les pratiques et les institutions globales.

\section{Unreliable and Crude Atrocities- Policing}

In Rwanda, between half and one million people were massacred in 1994 and the "international community" did nothing. When the "ethnic cleansing," previously observed in Croatia and Bosnia, started to occur in Kosovo in March 1999, NATO, presumably representing a segment of the "international community,"i.e., the European or North Atlantic region, initiated a "humanitar- ian intervention" in the form of heavy and protracted bombandment of Serbian forces and infrastructure in what is territorially left of Yugoslavia.

Both responses are reflections of what is wrong with the way our global polity is organized. In the Rwandan case, the states that could have facilitated preventive action by the United Nations-and it is now acknowledged that a force of $5,000 \mathrm{UN}$ soldiers would havebeen sufficient to prevent the genocide-simply did not have enough of a stake in the conflict. In the Kosovar case, while it was agreed that "something had tobedone," ground-forces action in tandem with air strikes was not acceptable, because of the risk to military units that individual states would have had to sustain. It has been more acceptable to kill (as "collateral damage") Serbian non-combatants and Kosovar refugees than to risk soldiers in a war that does not serve the national interest of the intervenors in a way clearly evident to their respective electorates. (For an argument that, indirectly, the wardoes serve the maintenance of U.S. hegemony, see Klare 1999 and Chomsky 1999. For useful reviews of various aspects of the Yugoslavian war of the 1990s, including the current NATO action, see Ramonet 1999; de La Gorce 1999; Samary 1999; di Francesco and Scotti 1999; Chiclet 1999 and Potel 1999.) The attack is on Serbia as a collective entity, rather than on those specifically responsible for the ethnic cleansing.

If we think of the NATO bombing as atrocities policing (and the failure of UN action in Rwanda as a failure of atrocities policing), we can compare such action with domestic policing. There are, of course, crucial differences; nevertheless, such a comparison is instructive. Let's say that a municipal authority used its police to systematically violate the basic rights of a particular ethnic group in order to drive it out or simply 
eliminate it. In that case, the superordinate state authority, after suitable efforts to non-violently reverse the action, e.g., through threats of punitive action, would have the responsibility to deploy its own police or military to accomplish a number of aims. The first is to protect the threatened population. The second is to minimize violence and, in particular, harm to non-combatants. The third is tobring those responsible to justice. In the process, the police or military forces involved will minimize risks to themselves, but not at the expense of risk to non-combatants.

How well and easily these tasks can be accomplished will depend on the relative strength of the superordinate state authority and the defying subordinate authority. Certainly it would be incumbent on the superordinate authority to muster all its forces to show overwhelming power and thus prevent furtherbloodshed. If this is not possible, then the situation is, of course, one of impending civil war. The superordinate authority then has to recognize that it has lost this authority and has to either concede this (possibly by permitting secession and negotiating for the best possible arrangement for refugees) or has to fight a war to reassert its authority. In fighting such a war, however, principles of responsible policing, such as minimizing the loss of life, protecting the innocent, avoiding displacement, etc., remain important. Large-scale bombing of the city to force its governors to surrender, without a more balanced strategy including on-the-ground action, is not consistent with responsible policing.

\section{The Sovereign-State System}

The relevance of this analogy is limited by the absence of a superordinate authority in the state system that characterizes our global polity. The capacity of the UN in this respect is severely limited and essentially depends on the five veto powers in the Security Council and their consensus. Inaction, procrastination, and excessively destructive action are all to be expected in this system. The latter emerged in the $1600 \mathrm{~s}$ in re- sponse to the failure of Europe's thenhegemonic power of the Austro-SpanishHabsburgs to put together a political system that could contain war in the way that the Roman Empire was thought to have done. This state system was then endowed to the rest of the world in the process of decolonization in the middle of the 20th Century.

Central to it is the principle of state sovereignty, which treats states as being formally equal, and entitled to non-intervention by other states and to manage its affairs as it sees fit. Democracy is not a requirement for this entitlement. (It should beremembered that democracy in Europe emerged after the principle of sovereignty was established in 1648 by the treaties of Westphalia at the end of the Thirty Years War-treaties that incidentally led to extensive refugee flows for religious reasons, because they established the right of rulers to determine the religion that was to be practised in their respective domains.) Nor were genocide or other atrocities within a state deemed to suspend its sovereignty rights, although the European powers allied against Germany and the Ottoman Empire in the 1914-18 war did use such incidents as justifications for intervention in the weakened Ottoman Empire. (The history of military conflict in Europe since 1648 reflects that within the state system, even a fundamental norm such as that of sovereignty may serve as a restraint, but never as an imperative that all states abideby.) The UN Charter allows only self-defence or more collective action against threats to international peace - not simply atrocities by states as justifications for military action against a state.

However, international practice has led to the increasing legitimation of humanitarian intervention, although there is so far no international law to supportit. (It is true that there is now an extensive body of international law prohibiting genocide, torture and slavery and requiring states to respect certain human rights, but there are no provisions for international enforcement.) Military action by India to stop Pakistani atrocities during the Bangladesh war of independence in 1971, by Vietnam in Cambodia to topple the massmurderous Pol Pot regime in 1978, and by Tanzania in Uganda in 1979 following the Idi Amin massacres were cases of unilateral humanitarian intervention. In all three cases, national defence interests on the part of the intervenors were involved, but ending the atrocities was a sufficient rationale. (That rationale, however, was not universally accepted at the time; Vietnam was heavily criticized and punished with economic sanctions by the United States, for example.) Then in the 1990 s, several instances of multilateral humanitarian intervention took place: thesupplement to the security intervention against Iraq (following its invasion of Kuwait) by enforcingno-fly zones for Iraqi forces in parts of Iraqi territory to protect the Kurds and the Marsh Arabs in the southeast; the failed intervention in Somalia; Bosnia; the West African intervention force Ecomog in Liberia and Sierra Leone. These are all to be distinguished from peace-keeping because they involved aggressive action against forces of the state or forces in the process of capturing the state.

Such intervention, however, is haphazard. It depends on the coincidence of humanitarian considerations with national interests, or alternatively requires humanitarian intervention to be cheap in terms of the national sacrifices for the intervenors. (This has been missing, for example, in the case of southern Sudan, whose population has been massively victimized by its state for a long time without any forcible external intervention. Rwanda is by no means the only instance.) Thus, even a state system that innovates by legitimating humanitarian intervention cannot assure reliable and responsible atrocitiespolicing.

\section{Beyond State Sovereignty}

Focusing on the structural problems of the present system raises the question of relevance. Is there a point to showing the inadequacies of the system that we have to work with? Is there even a plausible alternative? The answer to both 
questions is yes. I will first deal with the alternative and then with its significance for the present.

The state system is not the only way to organize the global polity. Two polar alternatives are a unitary world state and the anarchist option of a stateless world. In this short discussion I will dismiss, without the argumentitwould otherwise deserve, the latter alternative as unworkable within a useful time horizon. The former, which involves transferring state sovereignty to aglobal authority, is unattractive, even in a democratic form. Democracy at the global level cannot be but anaemic. While global democracy is by no means worthless, sacrificing the democracy of smaller jurisdictions to democracy at such an aggregative level seems too great a sacrifice. It can rightly be suspected as carrying the potential of global tyranny. In terms of the spectrum from anarchism to global sovereignty, the state system may thus actually appear as good a compromise as may be possible.

However, there is still another in-between position. It is that of federalism extended upward to the global level. (It could also be extended downward to the local level, so that local government at the community level has a certain amount of constitutionally assured autonomy from higher levels.) It would mean the abolition of sovereignty in favour of a dispersal of state authority among several levels. The global level, with appropriate democratic instruments-such as a global parliament based on elections, a constitution assuring certain basic rights and checks and balances involving a global judiciary and fundamental rights for lower-level state authorities-would be onelocus of responsibility for preventing atrocities within states. Just how much authority and policing power would be vested in it would be a matter of choice and contestation. The minimum, however, would have to be the capacity to prevent atrocities, even when they occur in big powers, such as Nazi Germany. (For one formulation of the world-federal case and scheme, see Glossop 1993.)
But isn't this utopian dreaming? Does this have any relevance to our present situation? In the short run, it clearly is utopian. In the long run, let's say with a time horizon of a century or so, however, it is not. There is no reason to expect change in the world's political system to slow down in the next century. Who could have imagined in 1900 that the colonial system, which then seemed absolutely secure, would nearly completely disappear as a formal system; that the pattern of world hegemony would change first from one based in western Europe to the bipolarity of the Cold War to the unipolar hegemony of the United States at the century's end; and that states would allow their sovereignty to be whittled away not only by capitalist processes, but also by international treaties reinforcing these processes? Why should change be any less drastic in the next century?

One scenario for the development of something like a global federation is the increasing emergence of global governance institutions to deal with various crises, ranging from economic instability through environmental degradation and disasters to violence resulting from terrorism, civil strife, and environmental wars. These global governance institutions may initially be as elitist as the IMF or even the UN (which can be described as democratic only by inordinately stretching the meaning of democracy). However, their establishment provides the opportunity and stimulus for democratizing them. One way of doing that would be through democratic global federalism.

The image of such an organization of the global polity has contemporary relevance to atrocities policing in two ways. One is a sense of direction provided to efforts of institutional innovation in the global polity. An example would be a standing military for the United Nations. This would allow multilateral intervention at least where there is consensus among the veto powens. It would also create pressure to abolish the great-power veto in the Security Council. (For such a proposal, see the Commission on Global Governance
1995, 233-41.) Another instance would be to strengthen the authority of the global courts. The basic point here is that the vision of a satisfactory structure for the global polity provides a sense of direction for institutional change, whether it is incremental or precipitous-as it might be in response to a disaster.

The second and closely related way in which such a vision is relevant is that, when responding to a particular humanitarian emergency, the institution-building consequences of such responses need to be considered. Does humanitarian intervention by NATO in Europe or by Ecomog in Africa (dominated as they are by the United States and Nigeria, respectively) further or hinder the eventual development of a global and democratically responsible capacity for atrocities policing? Does humanitarian intervention by a neighbouring state or a ring of neighbouring states advance or impede such capacity? Should multilateralism be maximized and made as broad as possible? Can this be done without impeding justified and needed action? Is the NATO intervention in Yugoslavia not only crude as policing, but also unfortunate in terms of its geopolitical consequences by reinforcing U.S. hegemony and thus impeding the emergence of democratic global governance? The proposed framework for thinking about such questions does not resolve disagreements. It will, in fact, make them more complicated by introducing long-term considerations alongside the more immediate issues, thus extending the points over which disagreement can emerge. Nevertheless, it is important to move beyond the fire-extinguishing approach to humanitarian emergencies so that it becomes possible to prevent them in the first place.

The purpose of presenting this framework has been to make some general points. The first is that the unreliable and reckless policing we have witnessed is a reflection of the structure of ourglobal polity; namely, a system that heavily bears the stamp of state sovereignty. At the same time, this 
14.

structure is not natural or inevitable; alternatives are conceivable and, in the long run, feasible. Finally, these alternatives will not emerge by themselves. They have to be made visible as images of possible futures and have to be struggled for. They have to be available as part of the standard repertoire of ideas when opportunities for radical change present themselves, as they do from time to time. II

\section{References}

Chiclet, Christophe. 1999. "Rise of the Kosovar freedom fighters." Trans!. L. Dale. Le Monde Diplomatique [English version published by Guardian Weekly] May 1999,6.

Chomsky, Noam. 1999. "Nato, master of the world." Le Monde Diplomatique [English version published by Guardian Weekly] May 1999, 1, 8-9.

Commission on Global Governance [Ingvar Carlsson, ShridathRamphal, etal.].1995. Our Global Neighbourhood. Oxford: Oxford University Press.

de La Gorce, Paul-Marie. 1999. "Behind the Rambouillet talks." Trans!. B. Smerin. Le Monde Diplomatique [English version published by Guardian Weekly] May 1999, 3.

di Francesco, Tomaso, and Giacomo Scotti. 1999. "Sixty years of ethnic cleansing." Trans!. E. Emery. Le Monde Diplomatique [English version published by Guardian Weekly] May 1999, 5.

Glossop, Ronald J. 1993. World Federation?: A Critical Analysis of Federal World Government. Jefferson, NC, \& London: McFarland \&Co.

Klare, Michael T.1999. "US aims to win on all fronts". Le Monde Diplomatique [English version published by Guardian Weekly] May 1999,2-3.

Potel, Jean-Yves. 1999. "Serbia's outlaw regime". Trans!. J. Stoker. Le Monde Diplomatique [English version published by Guardian Weekly] May 1999, 7.

Ramonet, Ignacio. 1999. "A fine mess." Trans!. L. Dale. Le Monde Diplomatique [English version published by Guardian Weekly] May 1999, 1, 9.

Samary, Catherine. 1999. "Confederation or explosion." Trans!. B. Smerin. Le Monde Diplomatique [English version published by Guardian Weekly] May 1999, 4. o

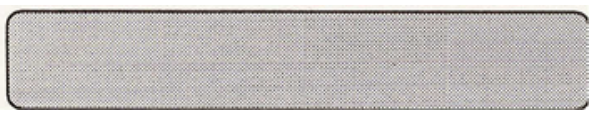

CRS/YLP PUBLICATIONS BOOKS

From Being Uprooted to Surviving: Resettlement of the VietnameseChinese "Boat People" in Montréal, 1980-1990

Lawrence Lam (1996)

$\$ 18.95$

Asylum-A Moral Dilemma W. Gunther Plaut (co-published with Praeger Publishers)

(1995)

Refugee Rights: Report of a Comparative Survey James C. Hathaway and John A. Dent (1995) $\$ 11.95$

Legitimate and IIlegitimate Discrimination: New Issues in Migration Edited by Howard Adelman (1995) $\$ 22.95$

African Refugees: Development Aid and Repatriation

Edited by Howard Adelman and John Sorenson (1994) \$39.90

Immigration and Refugee Policy: Australia and Canada Compared Edited by Howard Adelman, Lois Foster, Allan Borowski and Meyer Burstein (1994)

Volume One: Context, Policy and Implementation \$24.95 Volume Two: Settlement and Impact $\$ 24.95$

Breaking Ground: The 1956 Hungarian Immigration to Canada Edited by Robert $H$. Keyserlingk (1993) $\$ 6.99$

Taking Refuge: Lao Buddhists in North America

Penny Van Esterik (1992) \$12.95

Refuge or Asylum: A Choice for Canada Edited by Howard Adelman and C. Michael Lanphier (1991)

$\$ 18.95$

Refugee Policy: Canada and the United States Edited by Howard Adelman (1991) $\$ 20.95$

Soviet-Jewish Emigration and Resettlement in the $1990 \mathrm{~s}$ Edited by Tanya Basok and Robert J. Brym (1991) $\$ 4.99$

\section{REPORTS}

Paths to Equity: Cultural, Linguistic, and Racial Diversity in Canadian Early Childhood Education Judith Bernhard, Marie Louise Lefebvre et al. (1995) \$18.95

Cambodian Refugees in Ontario: An Evaluation of Resettlement and Adaptation

Janet McLellan (1995) \$12.95

Somali Refugees in Toronto:

A Profle Edward Opoku-Dapaah (1995)

$\$ 12.95$

Refugee Families and Children:

A Directory For Service Providers in Metro Toronto John Morris and Lydia Sawicki (1995)

$\$ 6.95$

Adaptation of Ghanaian Refugees in Toronto Edward Opoku-Dapaah (1993)

$\$ 12.50$

Report on the Workshop for African Community Groups in Toronto Edward Opoku-Dapaah (1992)

Directory of African Community Groups in Toronto Edward OpokuDapaah (1992) $\$ 12.50$

\section{OCCASIONAL PAPERS}

Fading Hopes: Struggles for Survival Among Cambodians Repatriated from Thai Refugee Camps Janet McLellan (1996) \$13.95

The Genesis of a Domestic Refugee Regime: The Case of Hungary Edited by Howard Adelman, Endre Sik and Géza Tessenyi (1994) $\$ 14.95$

So That Russia Be "Saved": AntiJewish Violence in Russia, Its Roots and Consequences

Tanya Basok and Alexander Benifand (1993) \$9.95

Please send your orders to:

Centre for Refugee Studies

Yor University

Suite 333, York Lanes

4700 Keele St.

Toronto ON Canada M3J 1P3 